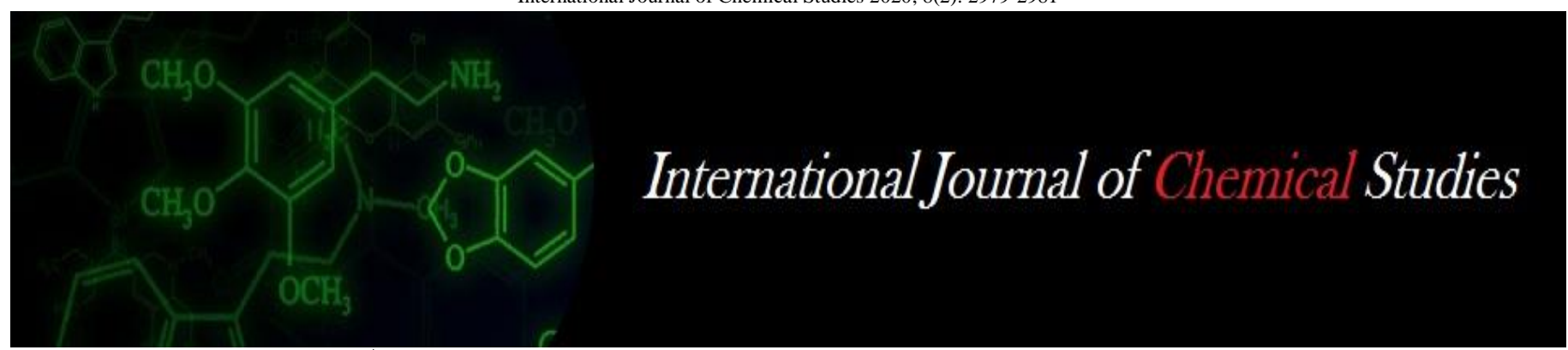

P-ISSN: 2349-8528

E-ISSN: 2321-4902

www.chemijournal.com

IJCS 2020; 8(2): 2979-2981

(C) 2020 IJCS

Received: 16-01-2020

Accepted: 18-02-2020

Roshan Kumar Yadav

Department of Plant Pathology,

S.K.N. College of Agriculture,

(Sri Karan Narendra Agriculture

University Jobner, Jaipur,

Rajasthan, India

\section{RP Ghasolia}

Department of Plant Pathology,

S.K.N. College of Agriculture,

(Sri Karan Narendra Agriculture

University Jobner, Jaipur,

Rajasthan, India

Rajesh Kumar Yadav

Department of Plant Pathology,

S.K.N. College of Agriculture,

(Sri Karan Narendra Agriculture

University Jobner, Jaipur,

Rajasthan, India
Corresponding Author: Roshan Kumar Yadav Department of Plant Pathology, S.K.N. College of Agriculture, (Sri Karan Narendra Agriculture University Jobner, Jaipur, Rajasthan, India

\section{Management of Alternaria alternata of tomato (Lycopersicon esculentum Mill.) through SAR activators in natural conditions}

\author{
Roshan Kumar Yadav, RP Ghasolia and Rajesh Kumar Yadav
}

DOI: https://doi.org/10.22271/chemi.2020.v8.i2at.9205

\begin{abstract}
The experiment was conducted at Department of Plant Pathology, S.K.N. College of Agriculture, Jobner (Rajasthan). Alternaria alternata was isolated from leaves of tomato and observed to be pathogenic under artificial conditions. It is cause heavy yield loss in rajasthan as well as in india. Among five systemic acquired resistance activators, salicylic acid was found most effective against Alternaria alternata in vivo conditions followed by , 2,4 Dichloroisonicotinic acid. All treatments as foilar spray were able to reduce disease severity over untreated control.
\end{abstract}

Keywords: Tomato, alternaria leaf blight, Alternaria alternata, SAR avtivators

\section{Introduction}

Tomato (Solanum lycopersicum L., syn. = Lycopersicon esculentum Mill.) belongs to the family Solanaceae and is one of the most remunerable and widely grown vegetables in the world. Among the vegetables, tomato ranks next to potato in world acreage and first among the processing crops.Tomato is grown for its edible fruits, which can be consumed either fresh or in processed form and is a very good source of vitamin A,B,C and minerals. Tomato cultivation has become more popular since mid nineteenth century because of its varied climatic adaptability and high nutritive value. Tomato is being exported in the form of whole fruits, paste and in canned form to West Asian countries, U.K., Canada and USA. Being the world's fourth most cultivated crop, with a production of 130 million tonnes and area of 5.2 million hectares, the tomato is an indispensible vegetable crop world over and, of course, for India. India is the third largest producer of tomato in the world after USA and China having an area of 0.88 million hectares with a production of 187.35 lakh tonnes during 2013-14 (Anonymous, 2014) ${ }^{[1]}$. In Rajasthan, tomato is cultivated over an area of 0.017 million hectares with an annual production of 0.817 lakh tonnes (Anonymous, 2014) ${ }^{[1]}$. In India, tomato crop is mainly grown in the states of Andhra Pradesh, Odisha, West Bengal, Karnataka, Bihar, Gujarat, Tamilnadu, U.P, Rajasthan etc.In Rajasthan, tomato crop is mainly cultivated in Jaipur, Dausa, Alwar and Chittorgarh districts.

There are several diseases on tomato caused by fungi, bacteria, viruses, nematodes and abiotic factors (Balanchard, 1992) ${ }^{[2]}$. Among the fungal diseases, early blight also known as target spot disease incited by Alternaria solani (Ellis and Martin) Jones and Grout, is one of the world's most catastrophic diseases. The causal organism is air borne and soil inhabiting and is responsible for early blight, collar rot and fruit rot of tomato (Datar and Mayee, 1981) ${ }^{[1]}$. It is very difficult to manage Alternaria solani, due to its broad host range, extreme variability in pathogenic isolates and prolonged active phase of the disease cycle. A coefficient of disease index of 71.66 per cent caused 78.51 per cent loss in fruit yield under severe epidemic (Datar and Mayee, 1981) ${ }^{[7]}$. The yield loss of tomato fruits was 78 per cent recorded at 72 per cent disease intensity by $A$. solani and each 1 per cent increase, reduced tomato yield by 1.36 per cent (Datar and Mayee, 1985) ${ }^{[8]}$. The disease appears on leaves, stems, petioles, twigs and fruits under favorable conditions resulting in defoliation, drying off of twigs and premature fruits drop and thus causing loss from 50 to 86 per cent in fruit yield (Mathur and Shekhawat, 1986) ${ }^{[9]}$. Pathogen also causes fruit rot in pre-harvest and post-harvest stages. Thus, infected fruits are disqualified in the market. 
A. solani is also one of the most common causes of seedling blight or damping off in tomato, causing dark lesions on the rootlets (Bose et al., 2002) ${ }^{[5]}$. Bessadat et al. (2014) [4] reported 46-90 per cent blight intensity in tomato due to Alternaria alternata in Algeria. Present investigation were carried out to test the efficacy systemic acquired resistance activators against leaf blight of tomato incited by Alternaria alternata.

\section{Materials and Methods \\ Induction of disease resistance in tomato against Alternaria alternata}

The experiment was carried out in mini plots $(1 \mathrm{x} 1 \mathrm{~m})$ with cultivar Arka Vikas. Arka Vikas, the susceptible variety of tomato was sown in mini plots with three replications. The systemic acquired resistance (SAR) activators viz., nicotinic acid (50,100\& 200 ppm), salicylic acid (50,100\& 200 ppm), hydrogen peroxide $(50,100 \& 200 \quad$ ppm $), 2,6-$ Dichloroisonicotinic acid $(50,100 \quad \& \quad 200 \quad \mathrm{ppm})$ and azoxystrobin $(50,100 \& 200 \mathrm{ppm})$ were tested by applying as root dipping (for 30 minutes) before transplanting and as foliar spray 35 days after transplanting (DAT). For inoculation, the spore suspension was applied 45 days after transplanting (DAT). The mini plots were covered with polythene sheet for 24 hours. Early blight severity on each leaf of the sprayed plants was recorded on a scale of 0 to 5, where $0=$ no visible lesions on leaf, $1=$ up to $10 \%$ leaf area affected, $2=11 \%-25 \%, 3=26 \%-50 \%, 4=51 \%-75 \%$, and $5=$ more than $75 \%$ leaf area affected or leaf abscised (Vakalounakis 1983) ${ }^{[13]}$. Leaves that were not completely unfurled during the inoculation were not assessed. The disease scale was converted into percentage of EB index (PEBI) for each plant using the following formula (Pandey et al. 2003) ${ }^{[10]}$.

$$
\mathrm{PEBI}=\frac{\mathrm{Sum} \text { of all ratings }}{\text { Number of leaves observed X Maximum disease rating }}
$$

The per cent disease control (PDC) was also calculated by using the following formula:

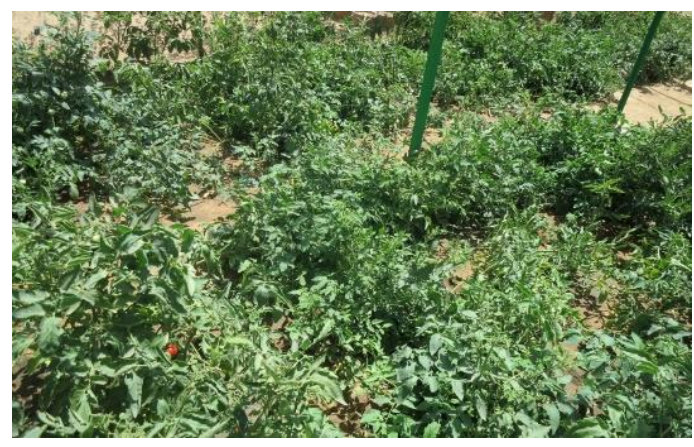

Tomato crop at experimental site

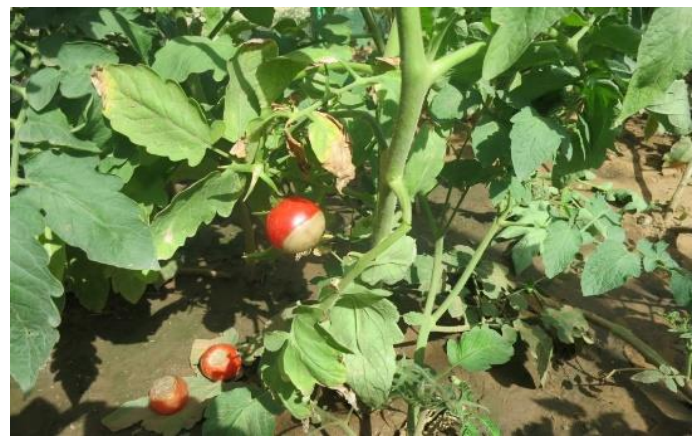

Symptoms on leaves and fruits

\section{Results and Discussion}

\section{In vivo evaluation of $\mathrm{SAR}$ activators}

A perusal of data (Table 1) revealed that minimum disease intensity was recorded with $200 \mathrm{ppm}$ concentration of salicylic acid $(34.00 \%)$ at 90 days after transplanting (DAT) followed by 2,6-Dichloroisonicotinic acid (36.00\%), hydrogen peroxide $(38.03 \%)$, nicotinic acid $(40.01 \%)$, azoxystrobin $(42.50 \%)$ and all were found significantly superior over control $(65.00 \%)$. Maximum reduction in disease intensity over control was observed with $200 \mathrm{ppm}$ concentration of salicylic acid $(47.69 \%)$ followed by $2,6-$ DIchloroisonicotinic acid $(44.62 \%)$, hydrogen peroxide (41.49\%), nicotinic acid (38.45\%) and minimum in azoxystrobin (34.62\%). Furthermore, all the tested concentrations of the SAR inducers showed reduced diseased intensity at reducing rate with increasing their concentration both at 60 and 90 days after transplanting (DAT). Presents results are in accordance with the results of Savitha (2004) [11], who observed induced systemic resistance against Alternaria blight in sesame by treating the seeds with salicylic acid and pseudomonas fluorescens. Chitra (2004) ${ }^{[6]}$ has also documented induced systemic resistance in groundnut plants against A. alternata by inoculating groundnut seeds with biocontrol agents. Salicylic acid, Jasmonic acid and ethylene have been used as SAR inducer against Alternaria leaf blight of carrot and found effective in reducing disease intensity and increasing yield (segarra et al 2006 and Bari and Jones 2009) $[12,3]$ 
Table 1: Efficacy of SAR activators against Alternaria leaf blight of tomato (in vivo)

\begin{tabular}{|c|c|c|c|c|c|c|c|c|c|c|c|c|}
\hline \multirow{3}{*}{ SAR activators } & \multicolumn{6}{|c|}{ Per cent disease intensity* } & \multicolumn{5}{|c|}{ Per cent disease control } & \multirow[b]{3}{*}{$\begin{array}{l}200 \\
\text { ppm }\end{array}$} \\
\hline & \multicolumn{3}{|c|}{ 60 DAT } & \multicolumn{3}{|c|}{90 DAT } & \multicolumn{3}{|c|}{ 60 DAT } & \multicolumn{2}{|c|}{ 90 DAT } & \\
\hline & 50 ppm & $\begin{array}{c}100 \\
\text { ppm }\end{array}$ & 200 ppm & 50 ppm & $\begin{array}{c}100 \\
\text { ppm }\end{array}$ & 200 ppm & $\begin{array}{c}\mathbf{5 0} \\
\text { ppm }\end{array}$ & $\begin{array}{c}100 \\
\text { ppm }\end{array}$ & $\begin{array}{c}200 \\
\text { ppm }\end{array}$ & $\begin{array}{c}\mathbf{5 0} \\
\text { ppm }\end{array}$ & $\begin{array}{c}100 \\
\text { ppm }\end{array}$ & \\
\hline \multirow[t]{2}{*}{ Hydrogen peroxide } & 12.50 & 10.00 & 9.50 & 43.30 & 39.50 & 38.03 & 35.23 & 48.19 & 50.78 & 33.38 & 39.23 & 41.49 \\
\hline & $(20.70)$ & $(18.43)$ & $(17.95)$ & $(41.15)$ & $(38.94)$ & $(38.07)$ & & & & & & \\
\hline \multirow[t]{2}{*}{ Salicylic acid } & 11.00 & 8.50 & 7.00 & 40.40 & 36.40 & 34.00 & 43.01 & 55.96 & 63.73 & 37.85 & 44.00 & 47.69 \\
\hline & (19.37) & $(16.95)$ & $(15.34)$ & $(39.47)$ & $(37.11)$ & (35.67) & & & & & & \\
\hline $\begin{array}{l}\text { 2,6-Di chloroiso-nicotinic } \\
\text { acid }\end{array}$ & $\begin{array}{c}10.40 \\
(18.81)\end{array}$ & \begin{tabular}{|c|}
9.50 \\
$(17.95)$ \\
\end{tabular} & $\begin{array}{c}8.50 \\
(16.95) \\
\end{array}$ & $\begin{array}{c}41.50 \\
(40.11)\end{array}$ & $\begin{array}{c}37.60 \\
(37.82) \\
\end{array}$ & $\begin{array}{c}36.00 \\
(36.87)\end{array}$ & 46.11 & 50.78 & 55.96 & 36.15 & 42.15 & 44.62 \\
\hline \multirow[t]{2}{*}{ Nicotinic acid } & 13.80 & 12.00 & 10.00 & 46.02 & 42.44 & 40.01 & 28.50 & 37.82 & 48.19 & 29.20 & 34.71 & 38.45 \\
\hline & $(21.81)$ & $(20.27)$ & $(18.43)$ & $(42.72)$ & $(40.65)$ & $(39.24)$ & & & & & & \\
\hline \multirow[t]{2}{*}{ Azoxystrobin } & 16.50 & 14.20 & 12.00 & 46.40 & 43.00 & 42.50 & 14.51 & 26.42 & 37.82 & 28.62 & 33.85 & 34.62 \\
\hline & (23.97) & $(22.14)$ & $(20.27)$ & $(42.94)$ & $(40.98)$ & (40.69) & & & & & & \\
\hline \multirow[t]{6}{*}{ Control } & 19.30 & 19.30 & 19.30 & 65.00 & 65.00 & 65.00 & - & - & - & - & - & - \\
\hline & $(26.06)$ & $(26.06)$ & $(26.06)$ & $(53.73)$ & (53.73) & $(53.73)$ & & & & & & \\
\hline & & $\mathrm{SEm} \pm$ & $\begin{array}{c}\mathrm{CD} \\
(\mathrm{p}=0.05)\end{array}$ & & SEm \pm & $\begin{array}{c}C D \\
(p=0.05)\end{array}$ & & & & & & \\
\hline & SAR & 0.19 & 0.55 & SAR & 0.44 & 1.27 & & & & & & \\
\hline & $\mathrm{C}$ & 0.14 & 0.39 & $\mathrm{C}$ & 0.31 & 0.90 & & & & & & \\
\hline & SARxC & 0.33 & 0.95 & SARxC & 0.77 & 2.20 & & & & & & \\
\hline
\end{tabular}

* Average of three replications

Figures given in parentheses are angular transformed values

$\mathrm{PDI}=$ Per cent disease intensity, DAT $=$ Days after transplanting

\section{Reference}

1. Anonymous. Follow the rules of IPS, New Delhi (2014), Indian Horticulture Database, National Horticulture Board, www.nhb.in.com, 2014.

2. Balanchard D. A colour atlas of tomato diseases. Wolfe Pub. Ltd., Brook House, London, 1992, 298.

3. Bari R, Jones JDG. Role of plant hormones in plant defence responses. Plant Mol. Biol. 2009; 69:473-88.

4. Bessadat N, Benichous S, Kihal M, Henni EH. Aggressiveness and morphological variability of small spore Alternaria spp. isolated from Algeria. J Exp. Sci., 2014; 2(2s):265-278.

5. Bose TK, Kabir J, Maithy TK, Parthasarathy VA, Som MG. Chemical management of seedling blight of tomato. Vegetable Crops. 2002; I(69):1-154

6. Chitra K. Eco-friendly approaches for the management of groundnut leaf blight caused by Alternaria alternata (Fr.) Keissler. M. Sc. (Agri.) Thesis, Tamil Nadu Agricultural University, Coimbatore, 2004, 136.

7. Datar VV, Mayee CD. Assessment of losses in tomato yield due to early blight. Indian Phytopath. 1981; 34:191$195 \mathrm{c}$

8. Datar VV, Mayee CD. Chemical management of early blight of tomato. J Maharashtra Agricultural Univ., 1985; 10:278-280.

9. Mathur K, Shekhawat KS. Chemical control of early blight in Kharif sown tomato. Indian J Mycol. Pl. Pathol. 1986; 16:235-236.

10. Pandey KK, Pandey PK, Satpathy S. Integrated management of diseases and insects of tomato, hot papper and cole crops. Tech. Bull. No. 9 IIVR Varanasi, 2003, 22.

11. Savitha AS. Variability and toxin studies of Alternaria spp., the incitant of blight of sesame. M. Sc.(Agri.) Thesis, University of Agricultural Sciences, Dharwad, 2004, 1-115.

12. Segarra G, Jauregui O, Casanova E, Trillas I. Simultaneous quantitative LC-ESI-MS/MS analysis of salicylic acid and jasmonic acid crude extracts of
Cucumis sativus under biotic stress. Phytochem. 2006; 67:395-401.

13. Vakalounakis DJ. Evaluation of tomato cultivars for resistance to Alternaria blight. Ann. Appl. Biol. 1983; 102:138-139. 